\title{
ENRIQUE PEÑA NIETO'S EDUCATION REFORM IN THE WAITING ROOM
}

\begin{abstract}
The analysis provided in this article aims to explain and disclose the processes that have influenced the education system in Mexico since the Aztec Empire, until the presidency of Enrique Peña Nieto. One of the issues presented in this paper is relation established by political party PRI (Partido Revolucionario Institucional) who rules Mexico for more than 70 years and institutions responsible for education, leading to centralization. The consequence of these processes is the attempt to introduce education reform by the government Enrique Peña Nieto. Without a doubt, the most important question asked in this article is "why education reform causes so many emotions among the teachers, especially members of the union and their associating organizations?".
\end{abstract}

\section{Key words}

education system, education reform, centralization, teachers' union, teachers' evaluation

"The business of the teacher is to produce a higher standard of intelligence in the community, and the object of the public-school system is to make as large as possible the number of those who possess this intelligence. Skill, ability to act wisely and effectively in a great variety of occupations and situations, is a sign and a criterion of the degree of civilization that a society has reached. It is the business of teachers to help in producing the many kinds of skill needed in contemporary life. If teachers are up to their work, they also aid in production of character" (Simpson \& Stack, 2010)

* Faculty of Political Science, Maria Curie-Sklodowska University in Lublin, Poland, e-mail:marnewf@gmail.com 


\section{Introduction}

Enrique Pena Nieto was sworn-in as President of Mexico on 1 December 2012 at the Federal Congress. During his inauguration speech, he proposed 11 structural reforms for the new administration. Some of the objectives of the reforms are to increase the growth and economic development in Mexico and strengthen democratic freedoms. The next day after taking office on 2 December, Peña Nieto signed an agreement with Gustavo Madero Muñoz, the president of the National Action Party (Partido Acción Nacional, PAN); Jesus Zambrano Grijalva, chair of the Party of the Democratic Revolution (Partido de la Revolución Democrática, PRD); and Cristina Diaz, the acting chair of the Institutional Revolutionary Party (Partido Revolucionario Institucional, PRI) known as the Pact for Mexico. The Pact contained 95 commitments 9 of which (commitments 7 to 15) are about education and how to raise its quality to better preparation of Mexicans as citizens and as productive people. For this, a legal and administrative reform in educational matters will be promoted with three initial and complementary objectives. First, increase the quality of basic education that is reflected in better results in international assessments such as PISA. Second, increase enrollment and improve quality in upper secondary and higher education systems. And third, that the Mexican State recovers governing of the national educational system and maintains the principle of secularism (Pacto por Mexico, 2012). With the consent of the signatories of the Pact for Mexico, President Pena Nieto initiated the legislative process and thus Education Reform in Mexico.

What is the Education Reform? To answer this question, it is necessary to know what are the norms that make up the so-called Educational Reform. In order to reform the education system in Mexico and achieve the objectives that were made in the Pact for Mexico, the administration of Enrique Pena Nieto had to introduce changes to Articles 3 and 73 of the Mexican Constitution, General Law of Education (Ley General de Educación), Law for the National Institute for the Evaluation of Education (Ley para el Instituto Nacional para la Evaluación de la Educación) and Professional Teaching Service Law (Ley del Servicio Profesional Docente). On the 26 February 2013 the Chamber of Deputies approved changes to Article 3, section II b, c, d, III, VII and VIII, and article 73, section XXV; and section IX was added to Article 3 of the Political Constitution of the United Mexican States. The Article 3 section IX established The National System 
of Educational Evaluation (Sistema Nacional de Evaluación Educativa, SNEE) and the National Institute for Educational Evaluation (Instituto Nacional de Evaluación Educativa, INEE) as a body responsible for the coordination of the system. INEE was granted full autonomy, and his task is to coordinate SNEE as well as to evaluate the quality, performance and results of the national education system in regard to basic and higher education both public and private (Constitución Política de los Estados Unidos Mexicanos, 2017). The fundamental change in Article 3 is the admission to the teaching service, promotion and permanence in the service with full respect of constitutional rights of education workers. The National Institute for the Evaluation of Education replaced the Teaching Career (Carrera Magisteria), ending with the discretionary allocation of "plazas". General Law of Education establishes the Educational Information and Management System (Sistema de Información y Gestión Educativa, SIGE) in charge of conducting a census of schools, teachers and students, supported by National Institute of Statistics and Geography (Instituto Nacional de Estadística y Geografía, INEGI), includes provisions such as prohibiting the collection of fees in basic or upper secondary education and encourages the State to inspect private schools. Professional Teaching Service Law regulates issues related to the evaluation of teachers. Every teacher who is already employed, have three attempts to pass evaluation exam, otherwise will be sent to another area or will be asked to retire. New employed teachers will have a trial period and will be evaluated each year to determine whether or not they meet the required standards. In the case of failure, they employment will be terminated. Teachers who fail to work three consecutive days without justification, or three times a month will be dismissed. The teacher evaluation is mandatory for all teachers and is not negotiable (La Ley General del Servicio Profesional Docente, 2013).

Without doubt, education is one of the most important aspects of the development and functioning of society. Unfortunately, the reform of education proposed by President Enrique Pena Nieto and his administrations instead of arousing hopes for positive changes in this matter caused waves of dissatisfaction and disapproval by many social groups associated with the education system. Education system refers to public schooling at the federal, state, or community levels and everything that is a part of it for example: law, policies, regulations, public founding, school facilities, compensation, employee benefits, books, computers, courses etc. (Glossary of Education Reform). 


\section{Education system in Mexico. From Aztec Empire to presidency of Felipe Calderón}

In order to understand the complexity and interrelationships that exist in the educational system of Mexico, let me briefly outline the most important events and reforms that have taken place in the education system in Mexico.

The modern State of Mexico known as The United Mexican States was established in 1824 after the War of Independence and the fall of Mexican Empire. For the purpose of this article I will refer term Mexico to the territory on which The United Mexican States were established. Education system in Mexico has a long tradition. Aztec's civilization was one of the first in the world to have a mandatory education for all kids regardless of gender, social status, whether noble, commoner or slave. Until the age of fourteen all the kids were educated by the parents, and after that, the boys attended either the noble school, called a calmecac, or the commoners' school, the telpochcalli. The girls were taught crafts of home and how to be a good wife and mother. Girls were not taught how to read and write. Teachers were greatly admired.

The conquest of the Aztecs by Spain brought radical transformations to the institutional framework but some of the institutions were adopted and legitimate for the Nahuas. After the fall of Tenochtitlán, Franciscans, Dominicans and Augustinians began the tasks of Christianization, under the idea that education in childhood was the way to social transformation. It was possible for them to mold the faith in the children and used them for their propose. Since the religious orders were the only ones interested in educating the conquered people, they were the governing authority of the educational policy, with the consent of the crown. The school organizations maintained not only teaching in the language of the Nahuas, but also the oral method of knowledge transmission, which nowadays is still the main one in the indigenous schools around Mexico. The success of the religious orders, mainly of the Jesuits, was largely due to their ability to manage institutional change by adapting the existing institutions to the new conditions. It can also be established that the institutional change, although abrupt, was not completely radical (Vértiz Galván, 2017).

During XVII and XVIII centuries, the educational system was constituted with organizations of church schools, of the private teachers associated in the teacher's guild "Nobilismo", and the only one secular school for girls, established by the Basque merchants in Mexico City, in 1767. On the one hand religious orders had permission to create teaching curriculum and new schools' openings, and on the other hand teacher's union, which generated the first formal primary 
education regulations. The City Council of Mexico City had the authority to give a license to teach and supervised the union. The system worked until the Bourbon's reforms, which tried to impose a new system of legitimacy by limiting power of the church. The reform attempted the secularization of the Indian's doctrine (the construction of the catholic identity of the colonial Indians), the expulsion of the Jesuits, the appointment of the Spanish priests instead creoles in the indigenous parishes, establishing of Spanish schools in indigenous towns, and prohibition of the use of the native language in preaching. The church had been replaced with the viceroy in the matter of educational policies, although the teacher's union continued to be the authority in the private schools. One of the first policies was the implementation of measures to supervise the teachers' payment from the funds of each community by the government.

The period after the War of Independence is characterized by a process of institutionalization of the system of legitimacy of the State, and the policy that sought to update the humanist culture of the people to have literate citizens, educated in their civil rights, industrious, with knowledge of their obligations to the community and committed to the republican government. That implied for the State to assume two important innovations: to extend the primary education to masses form and to replace the mental structure of the dogmatism by the curiosity, the investigation and the questioning. In fact, only the urban population was expected to be incorporated these changes; the rural masses had been and would continue to be illiterate. Article 3 of Mexican Constitution 1857 ensured that teaching was free, and the law determined which professions need title for its exercise, and what requirements should be issued (Constitucion Politica de la Republica Mexicana, 1857). Benito Juarez Mexican president issued the Organic Law for Public Instruction for Federal District and federal territories based on secular education, elimination of catechism and biblical history, replaced by ethics. Despite some success achieved by the government, the political problems left the educational system in economic bankruptcy. Intensive military activity and foreign interventions, which occurred during this period led government to used public education funds to finance the wars, and a certain degree of security was not reached again until the restored republic in 1867.

The Porfiriato ${ }^{1}$ allowed modernity and economic development enter to Mexico. From the beginning, he laid the foundations for a system of legitimacy whose legacy reaches our days: that of providing an elementary education that

1 Porfiriato is the period of Mexican history when Porfirio Diaz held power as president of Mexico almost continuously from 1876-1911. 
is obligatory for all. The English industrial revolution sowed the need to prepare educated men in various trades. The system of legitimacy evolved with the influence of positivism introducing the idea of educational modernity, "the basis of current education was developed in those years that go from 1876 to 1910 ", started physical education in schools, modern pedagogy was introduced, normal schools $^{2}$ (first one was created 1885 in Mexico City) were created and multiplied, technical careers were offered to workers, and higher education reached a golden age (Vértiz Galván, 2017)3. Unfortunately, the changes in education didn't take a place in equal manner in the entire Republic. The lowest percentage of illiteracy among the Indians was in the north and central parts of Mexico, the highest in the south. Generally, $84 \%$ of the Indian population was illiterate. The government participation in public education and educational policy defiantly transformed national educational system. The Obligatory Instruction Act of 1888 gave the right to formulate the teaching programs only to executive power. With the beginning of the twentieth century the new institutions were created, Undersecretary of Public Instruction (Subsecretaría de Instrucción Pública) in 1901, Secretariat of Public Instruction and Fine Arts (Secretaría de Instrucción Pública y Bellas Artes) in 1905, and in 1910 National University (Univesidad Nacional).

During the revolutionary period 1910-1946 (Buchenau, 2013), the process of shaping the Mexican educational system had a significant setback. After all, on 5 February 1917 a new Constitution was adopted. The Article 3 granted the right to secular, compulsory and free education to every Mexican citizen. Also, the State received more power to coordinate and monitor the public and private schools. With the suppression of the Secretariat of Public Instruction and Fine Arts determined by the Constituent Congress, the educational system of the new revolutionary regime had problems to consolidate. In the decades of the 20 s and 30s, discussions about the type of education that should be promoted by the governments of the revolution absorbed all the efforts of intellectuals and educators. Catholic education, secular education, the rationalist school, active education, socialist education and many others were constantly confronted, and these permanent discussions did not allow the efforts to be focused on real improvement of the methods, institutions and institutions and educational organizations (Vértiz Galván, 2017). Thanks to the activity of José Vasconcelos Calderon the national system of education was established. He expanded the

\footnotetext{
2 Normal school is institution for the training of teachers.
} 
system of "preparatoria" (upper secondary schools or high schools) and refunded the National University to coach administrative elite, but more significant was the creation of a system of schooling whose main purpose was to assimilate rural population and ethnic minorities into society to prevent possible internal conflicts. 3 October 1921 Mexican Congress instituted Secretariat of Public Education (Secretaria de Educacion Publica, SEP) and Vasconcelos Caolderon became the first secretary. In 1921 the number of primary education teachers increased from 9560 in 1919, to 25 312; there were 35 preparatory schools, 12 law schools, 13 medical schools, 6 engineering schools, 5 pharmaceutical schools, 36 normal schools, 3 nursing schools, 2 notary schools, 10 of fine arts and 7 of clerics (Presidencia de la República, 2013). Between 1922-23 Obregon's government spent more than 50 million of pesos on education. To compare between 1918-1919 Carranza's government has allocated less than five million (Deeds, Meyer \& Sherman, 2011).

Significant changes in the education system occurred during the presidency of Lázaro Cárdenas from 1934 to 1940. Shortly before the end of the year of 1934 the Congress of the Union approved the proposal of the National Revolutionary Party (Partido Nacional Revolucionario, PNR) to modify the Article 3 of Mexican Constitution. Already reformed, the text established that education provided by the State should be socialist, exclude all religious doctrine and combat fanaticism by inculcating a rational and accurate concept of the universe and social life. It also expanded the powers of the federal government both to control the various levels of the education system and to monitor the operation of private schools. Socialistic education was to serve as an agent for social and cultural change. The school's activities were to be directed toward the working class by collaborating with trade unions, cooperatives, and agrarian organizations (Weyl \& Weyl, 1939). The teacher was to be a social leader, an advisor, and an orienteer. Cárdenas encouraged workers including teachers to formation of unions. In 1934 the League of Education Workers (la Liga de Trabajadores de la Enseñanza, LTE) and the Workers' University and the National Federation of Education Workers (la Universidad Obrera, la Federación Nacional de Trabajadores de la Enseñanza, FNTE), were created and 1936 the Confederation of Workers of Mexico (Confederación de Trabajadores de México, CTM), which gave beginning of the Trade Union of Workers of the Teaching of the Mexican Republic (Sindicato de Trabajadores de la Enseñanza de la República Mexicana, STERM). Despite attempts to unify teachers, it was difficult due to ideological differences and struggles for power. Cárdenas brought the new labor federations into the state-party, changing its name from PNR to the Party of the Mexican 
Revolution (Partido de la Revolución Mexicana, PRM). Cárdenas who is consider most left-wing president is responsible for creation of corporative system, where the state-party dominates the unions and workers.

30 December 1943 Unity Congress inspired by Mexican president Ávila Camacho created the National Educational Workers Union (Sindicato Nacional de Trabajadores de la Educación, SNTE), as a result of the amalgamation of all teacher groups, trade unions, federations and teachers' confederations.

Miguel Alemán Mexican president from 1946 to 1952 launched number of public works. Many primary and secondary schools were built, but students' attendance stayed low. Of the six million schoolchildren in the age six to fourteen, fewer then, 2.25 million attended classes on regular basis. The 1950 census revealed that only 5 percent of rural children finished the sixth grade (Deeds, Meyer \& Sherman, 2011). The most impressive project of Alemán was the construction of the University City, which became house for the National Autonomous University of Mexico (UNAM). Since the 1950s, a deepening correlation between SEP and SNTE was initiated. The leaders of both institutions tried to control the teachers by nominating bureaucrats, collaborated with the Institutional Revolutionary Party (Partido Revolucionario Institucional, PRI) ${ }^{4}$ officials, SEP provided funds for non-existent teaching posts. In this way, the government received the support of teachers during the elections at the federal, state and local level, and the union activists, in turn, received lucrative positions in the state institutions. This is a phenomenon that exists for this day.

By 1963 during the presidency of López Mateo the spending on education from the state budget on education was twice as great as on defense. Jaime Torres Bodet, Secretary of Education issued National Plan for the Expansion and Improvement of Primary Teaching (El Plan Nacional para la Expansion y Mejoramiento de la Enseñanza Primaria), known popularly as the Eleven Year Plan (El Plan de Once Años), which main goal was to increase in the quantity and quality of teachers to be trained. Unfortunately, teachers' organizations had an effective veto over any actions to carry out reforms. In 1979 group of teachers from Chiapas, Tabasco, Guerrero and the other states have found The National Coordinating Committee of Education Workers (Coordinadora Nacional de Trabajadores de la Educación, CNTE). CNTE is a teachers' movement not a union, and its development was a reaction some of the members of SNTE to the growing dependence of teachers' union from PRI and SEP. CNTE refers

${ }^{4} 1946$ the Party of the Mexican Revolution changed its name to the Institutional Revolutionary Party. 
to the leftist ideas, initiated by the Cárdenas, which regained its popularity in the 1960s and 1970s. The strong presence of CNTE for this day is in Chiapas, Oaxaca, Guerrero and Michoacán, which are the poorest states of Mexico and with the largest population of indigenes people.

Educational reform was one of the major goals of president Carlos Salinas, involving the largest federal bureaucracy in Mexico, the SEP, and the largest labor union in Latin America, SNTE, and led to comprehensive institutional change (Roett, 1995). Under the pressure of the striking teachers demanding wage increases and democratization of union, Salinas requested resignation from Carlos Jonguitud Barrios, who for eighteen years served as the president of SNTE and replaced him with Elba Esther Gordillo. His second move was announcement of the educational reform: The National Agreement for the Modernization of Basic Education (Acuerdo Nacional para la Modernización de la Educación Básica, ANMEB) signed by SEP, SNTE and governors of 31 states of the Republic in May 1992. This program had three main objectives. The first was associated with the reorganization of the educational system, which consisted in the transfer of the education sector, formerly administered by the federal government, to the States. The transfer included 513,974 teachers, 116,054 administrative posts, 3,954,000 hourly salaries, 1.8 million pre-school students, 9.2 million primary students, 2.4 million secondary students, and 22 million diverse materials. The second objective was the reformulation of regional educational content, in which states received the authority and the right to propose changes. Proposals are evaluated by SEP and, if accepted, included in the Free Textbook System (Sistema Nacional de Libro de Texto Gratuito). In this respect, the role of the states is to propose content, while the federal government decides and puts the proposal into practice. The last objective, the revaluation of teaching activities, consisted in launching Carrera Magisteria, for basic education teachers and union members. Overall, the objective was to improve teachers' welfare through better salaries and housing policies (Lopez-Acevedo, 2004). The Agreement of 1992 implied a tremendous transfer of assessments from the federal treasure to the states, and that gave SNTE's leaders unlimited power. In 1994 Mexico became a member of The North American Free Trade Agreement (NAFTA) and The Organization for Economic Co-operation and Development (OECD). That has symbolized Mexico's entry into the process of globalization and thus required changes to the Mexican education system.

Presidential elections in 2000 brought unexpected changes to the political scene of Mexico. For the first time in 71 years, the PRI candidate lost the presidential election, and the National Action Party (Partido Acción Nacional, PAN) 
candidate Vincente Fox had won. Six years later, Fox's success will be repeated by another PAN candidate, Felipe Calderon. PRI's corporatist system and his relations with SNTE made PAN's educational reform promises impossible to put into practice. Elba Esther Gordillo as a president of the SNTE established personal and political alliances with PAN from 2000 to 2012, which allowed her to secure benefits for union members. Government expenditure on education, total (\% of government expenditure) during the PAN regime was relatively high. In 2003 it was 22.44 percent and much higher than OECD members, which was only 12.29 percent (World Bank). Fox decreed the creation of the National Institute of Education Evaluation (Instituto Nacional para la Evaluación de la Educación, INEE) to evaluate the quality, performance and results of the national education system in pre-school, primary, secondary and higher education. One of the creations of INEE is the Evaluación Nacional del Logro Académico end Centros Escolares (ENLACE), the national exam every student in public and private school takes in Mexico. It is a test designed to obtain additional information on education in Mexico in the areas of Math, Science and Spanish for students in 3rd, 4th, 5th, 6th, 9th, and 12th grades. As of 2006, ENLANCE, EXCALE and PISA tests began to be applied and in 2008 for the first-time new teachers were selected through the national entrance exam. The fact that the exam was not obligatory did not stop the phenomenon of trading teaching positions so-called "plaza"

\section{Necessity of reform}

Since the presidency of Salinas, we could observe some change in the way of thinking about the reform of the educational system in Mexico. Early reforms were oriented towards quantitative changes, e.g. by increasing the number of students from 3 million in 1950 up 32 million in 2011, schools and teachers. The efforts of Mexico to join the group of developing countries and to be an actor in a globalizing world, forced him to make changes of a qualitative nature as well. Without doubt, membership of Mexico in group of OECD countries was and is a motivating factor.

Enrolment rate of students on all levels of basic education 5-14-year-olds in 2012 was 100\%, but Mexico has one of the smallest proportions of 15-19-yearolds enrolled in education, only $53 \%$, where the OECD average is $84 \%$. Most

5 It is a "position" or "teaching post", and the possession of a plaza, implies a sense of property ownership. 
young children attend primary school but only $62 \%$ reach secondary school. At secondary level about half of students drop out and only a quarter reach higher education. In 2011 Mexico spent about 6.2\% of gross domestic product on education, but corruption means the money does not translate into real gains in the quality of education, about $92 \%$ goes to staff compensation, and $83 \%$ to teachers' salaries; the OECD average is just over 63\% (OECD 2012).

The OECD points out that the Mexican educational system reflects a low quality in the education of its students based on the low results derived from the application of national and international tests. The performance of the students is diverse and depends on varies aspects such as: psychological, economic, political, social, cultural, motivational, study habits, among others. There are great gaps in educational quality due to the socioeconomic level to which the students belong, a situation that is present throughout the national territory.

According to the results of PISA 2012, 55\% of Mexican students do not reach the level of basic competences in mathematics (average OECD: 23\%), less than $1 \%$ of Mexican students aged 15 achieve the highest levels of proficiency in mathematics (OECD average: 13\%).

The average student in Mexico gets 413 points in mathematics. The average score in the OECD is 494, a difference with Mexico that is equivalent to almost two years of schooling. In reading, the picture is similar. $41 \%$ of Mexican students do not reach the basic competency level (OECD average: $18 \%$ ), less than $0.5 \%$ of 15-year-old Mexican students achieve the highest levels of proficiency (OECD average: $8 \%$ ). The average student in Mexico gets 424 points. The average score in the OECD is 496, a difference with Mexico that equals just under two years of schooling. And in science, $47 \%$ of Mexican students do not reach the level of basic skills in science (average OECD: 18\%), less than 0.5\% of Mexican students of 15 years of age attain the highest levels of proficiency in science (OECD average: $8 \%$ ). The average student in Mexico gets 415 points in science. The average score in the OECD is 501, a difference with Mexico that is just under two years of schooling (OECD 2012).

To ensure the quality of education is necessary to have teachers how are able to perform properly. In the Teaching and Learning International Survey (TALIS) ${ }^{6}$

6 The Teaching and Learning International Survey (TALIS) collects internationally comparable data on the learning environment and the working conditions of teachers in schools across the world with the aim to provide valid, timely and comparable information from the perspective of practitioners in schools to help countries review and define policies for developing a high-quality teaching profession. 
survey, the school principal of around 70\% of Mexican lower secondary teachers reported that the teacher's late arrival, absenteeism or lack of pedagogical preparation hindered the quality of education provided at the school. A Mexican teacher works, on average, 800 hours a year for 42 weeks hitting above the OECD average - 762 hours in 38 weeks. Of them $60.5 \%$ have earned a university degree and $23.3 \%$ come from training schools (teachers' colleges). The level of specialization, however, is low: only $8.9 \%$ hold a post-graduate degree. According to Alberto Serdán Rosales the unions have had control of 50\% of appointments since the 1990s. They also decide promotions and tenures based on a system of points in which union functions are worth more than academic activities. "The unions do as they please with appointments and salaries because of the political power they hold based on the points system" (Calderón, El País, 2013). Until 2011, 92 percent of teachers said they had obtained their position by simply paying for it or being passed down to family members without the professional preparation. We can observe situation where somebody who teaches history, math, or other subject has no qualification to do it. This situation is very often observed in rural schools. $10.3 \%$ of teachers holds two or more "plazas" and the average number per teacher is 1.2 and $8.2 \%$ of schools' principals. There are many irregularities in the payment of teachers. The SEP reports a case where a teacher gave classes in Nuevo León in the morning and in the afternoon in Quintana Roo. Also, the well-known drug boss of cartel Los Caballeros Templarios in Michoacán, "La Tuta" or "El Profe" has received money as a teacher, from the Secretariat of Public Education of Michoacán, which for nine years, until 2010. In the first trimester of 2010 he took in 51.000 pesos (3800 dollars) (Calderón, El País, 2013). SEP is unable to find so called "ghosts' teachers" or "phantoms" in number of 39 thousand 222 who collects salary every month. More than 298 thousand teachers and education workers are not in the schools where they are supposed to work, because they are "commissioned" in union or administrative functions, they resigned, they have already retired, they have died or never come to work at the school where they collect their salaries.

\section{Red light to reform}

History of Mexican education system and the attempts to reform the system clearly shows that is not an easy task. Why is like that?

The network of ties and interrelations between SNTE and the State institutions, which was built over decades, is too strong to be amicably settled and without losses for each party. Despite revealing the high level of corruption of 
SNTE's leaders, its popularity is not diminishing among teachers. In the poorest states of Mexico, Chiapas, Oaxaca, Michoacán and Guerrero SNTE has been replaced by CNTE. In contrast to SNTE, CNTE is an organization not a union that doesn't agree to any negotiations with the government and it can bury all attempts to improve the conditions in education. Since the beginning of 2013, CNTE has been responsible for hundreds of strikes, demonstrations, roads blocks, and empty schools, where hundreds of thousands of students couldn't attend regular classes. It should be underlining that teachers participating in protests teach at the level of basic education.

As I mentioned earlier, teachers protest against the evaluation of their knowledge and teaching skills. Why do they fear the evaluation? From the total number of 1599 thousand 727 teachers in Mexico of whom 73.9\% have a bachelor's degree, $11.3 \%$ master's degree, $5.3 \%$ Normal schools, $2.6 \% \mathrm{PhD}$, and $6.9 \%$ includes teachers who declare to have a primary, secondary and high school level. Only $7.2 \%$ and $0.6 \%$ of teachers with master and doctorate degrees give classes in the basic education. In basic education of every 100 teachers, 63 have as their main field of study the field of teacher training and 17 in a related field such as science in the education. The remaining 20 have careers in the fields of social sciences, administration and law, the arts and humanities, natural sciences, computer sciences, as well as engineering, manufacturing and construction. Eight in 10 teachers who took a non-mandatory 2008 evaluation exam didn't pass, according to Mexicanos Primero, a nongovernmental organization advocating teacher evaluations and education reform. In 2014, the total of applicants for basic teaching positions and teaching technicians was 130512 (78.7\%). The application was issued for graduates of public and private normal schools, and for public and open - for graduates of other institutions of higher education (IES), including those of the system of the National Pedagogical University (UPN). Most the applicants were placed by graduates from normal schools 72 870, and 57642 from other institutions. The table below shows candidates for the teaching positions from the state of Mexico, which are most against the teacher's evaluation.

Applicants from Chiapas and Guerrero shows the lowest level of performance, only around $20 \%$ passed evaluation exam, and in the case of Michoacán is little over 33\% and Oaxaca 44\%. The candidates form normal schools which are dedicated to educating new teachers have defiantly better performance than candidates from other institutions. 
Table 1. Distribution of results of the applicants (passed and failed) by type of graduation school entity in basic education, 2014-2015

\begin{tabular}{|l|r|r|r|r|r|r|r|r|r|}
\hline \multirow{2}{*}{ State } & \multicolumn{3}{|c|}{$\begin{array}{c}\text { Evaluation results per } \\
\text { state }\end{array}$} & \multicolumn{3}{c|}{$\begin{array}{c}\text { Applicants form normal } \\
\text { schools }\end{array}$} & \multicolumn{2}{c|}{$\begin{array}{c}\text { Applicants from public } \\
\text { and open schools }\end{array}$} \\
\cline { 2 - 12 } & $\begin{array}{c}\text { Total } \\
\text { number }\end{array}$ & $\begin{array}{c}\text { Passed } \\
\%\end{array}$ & $\begin{array}{c}\text { Failed } \\
\%\end{array}$ & $\begin{array}{c}\text { Total } \\
\text { number }\end{array}$ & $\begin{array}{c}\text { Passed } \\
\%\end{array}$ & $\begin{array}{c}\text { Failed } \\
\%\end{array}$ & $\begin{array}{c}\text { Total } \\
\text { number }\end{array}$ & $\begin{array}{c}\text { Passed } \\
\%\end{array}$ & $\begin{array}{c}\text { Failed } \\
\%\end{array}$ \\
\hline Chiapas & 6128 & 20.2 & 79.8 & 1519 & 40.1 & 59.9 & 4609 & 13.6 & 86.4 \\
\hline Guerrero & 4810 & 23.1 & 76.9 & 2949 & 27.1 & 72.9 & 1861 & 16.8 & 83.2 \\
\hline Michoacán & 1480 & 33.2 & 66.8 & 642 & 37.9 & 62.1 & 838 & 29.7 & 70.3 \\
\hline Oaxaca & 113 & 44.2 & 55.8 & 32 & 53.1 & 46.9 & 81 & 40.7 & 59.3 \\
\hline National & $\mathbf{1 2 3 0 3 8}$ & $\mathbf{4 0 . 4}$ & $\mathbf{5 9 . 6}$ & $\mathbf{6 9 9 6 2}$ & $\mathbf{4 5 . 4}$ & $\mathbf{5 4 . 6}$ & $\mathbf{5 3 0 7 6}$ & $\mathbf{3 3 . 9}$ & $\mathbf{6 6 . 1}$ \\
\hline
\end{tabular}

Source: Own elaboration base on date from Instituto Nacional para la Evaluación de la Educación, "Los docentes en México", Informe 2015.

Another reason for the protests is issue related to the loss of privileges, especially the financial ones. Distributions of federal funds on education by the states and union makes the whole process very complicate. In Chiapas exits 1,091 and in Guerrero 540 different categories of salary distribution. Lack of transparency allows some 70 teachers makes 193 thousand 458 pesos per month as the president of Mexico. The most famous case is of maestro A. Ramirez Z. from Oaxaca who received 603 thousand 069.40 pesos per month in last quarter of 2013. The National Flag preschool, key CCT 12DJN2835G, located in Iguala, Guerrero, has a payroll of 6 people while the School Census reports that only two people work there and only have one student. The payroll per month is $\$ 85,533.90$. The cost per student of this school is higher than the tuition fees of Stanford University in California, USA (Instituto Mexicano para la Competitividad, 2014).

Leaders of CNTE from Chiapas, Guerrero, Michoacán and Oaxaca also belong to financial elite in the education. Rubén Núñez Ginez, leader of Seccion 22 of the CNTE in Oaxaca, received 100,164 pesos per month and 300,494 pesos total in the first trimester of 2015 without entering the classroom. Juan José Ortega Madrigal, leader of Seccion 18 of the CNTE in Michoacán received 170,841 pesos in the first trimester of 2015. Adelfo Alejandro Gómez, leader of Seccion 7 of the CNTE in Chiapas made 75,427 pesos in the first three months of 2015 (Hernández, Excelsior, 2015). The article 78 of the Law on Professional Teaching Service, says that all teachers or education workers who have a commission that prevents them from teaching in front of a group, as established by their position, "shall be separated from the service, without any salary, while the employment, 
position or commission lasts." (La Ley General del Servicio Profesional Docente, 2013). Amount of money made by these leaders can improve infrastructure of many schools in their states. I believe that the actions planned by the leaders of the CNTE are not intended to protect the rights of teachers but their vested interests.

This is due not only to the numbers I have quoted but to my own observation. From 2009 to 2016, I had lived in Morelia, Michoacán, and worked as a teacher at the private university of Tecnologico de Monterrey. I was often a victim of activities carried out by CNTE's members and normal school students. In many cases, asked by me why they protest, they could not explain it to me. Some members of CNTE were forced to take part in demonstrations under the financial punishment.

In many cases, the actions carried out by the teachers and leaders of CNTE are directed not only against the education reform but the federal government. The activity of organized crime groups, self-defense movements, lack of respect for the rights of indigenous peoples and general public dissatisfaction with PRI policy leads to escalation of violence.

\section{Conclusions}

Mexico is the country with a vast territory, $13^{\text {th }}$ in the world, one of the most populated, $11^{\text {th }}$ place in the world and with 56 Aboriginal groups speaking 68 indigenous languages. Considering the two-basic information, territory and population, we can conclude that introducing changes in the education system was not and is not easy task.

The colonization of the territory of what is called now, Mexico by the Spaniards has led to strong divisions among the populations of this area. The indigenous population, which constituted the majority of the population, was reduced to social underclass, and newcomers from Europe climbed on the top of the social pyramid. Along with Christianization, indigenous people were deprived of its traditional social institutions, one of them was education. Unfortunately, the colonizers did not develop institutions that could replace the earlier ones and provide education for indigenous people. Education was reserved only for those who were "whites" and rich.

The independence of Mexico from Spain in 1821 failed to solve the problem also, and various political groups did not address the reform of the education system. The big step took place in the middle of the nineteenth century with the presidency of Benito Juarez, who led to the separation of power between the 
State and the Church, introducing secular teaching to schools. The changes in the education system that have occurred since the time of Benita Juarez to the early 90's of the twentieths were mainly quantitative changes, by increasing the number of students, expanding the infrastructure and by hiring more teaching staff. Unfortunately, there was no qualitative change in education along with quantitative changes.

With the Mexico's affiliation to NAFTA and OCED, there was a need to change the way to look at education. By improving the quality of education of Mexican youth, can allow Mexico to compete with other countries, but a welltrained teaching staff is needed. It cannot be that teacher who does not have the right skills, gives classes. Working as a teacher in Mexico, I often witnessed the situations, especially in rural schools, where Spanish teachers could not write correctly. The lower the level of staff, the lower the level of students. In my opinion, the teachers' protests against the reform of education proposed by Enrique Pen Nieto's government arise from the general misunderstanding of the proposed changes, defending their own interests by the leaders of these protests, public dissatisfaction with the government, as well as strong separatist traditions and non-compliance with federal rule in some states, e.g. Zapatistas in Chiapas, or autodefensa in Michoacán.

Without question Mexican education system must undergo deep changes, by improving quality of service which benefits students not interest groups. The political changes that took place with the election of Andrés Manuel López Obrador as the new president of Mexico will be the factor shaping the future of education in Mexico. Let's hope that the education issue was not just an electoral slogan, but it will be treated seriously by the new government.

\section{REFERENCES}

Buchenau, J. (2013). The Mexican Revolution at its centennial. Latin American Research Review, 48(2), 185-187.

Calderón, V. (2013). The state of education in Mexico. EL País. Retrieved from https:// elpais.com/elpais/2013/09/06/inenglish/1378504057_563224.html.

Cámara de Diputados del H. Congreso de la Unión. (2017). Constitución Política de los Estados Unidos Mexicanos. Mexico City: Diario Oficial. Retrieved from http://www. diputados.gob.mx/LeyesBiblio/pdf/1_150917.pdf.

Cosío Villegas, D. (2007). La constitución de 1857 y sus críticos. Mexico City: Fondo de Cultura Economica.

Deeds, S., Meyer, M., \& Sherman, W. (2011). The course of Mexican History. New York \& Oxford: Oxford University Press. 
Hernández, L. (2015). A tres líderes de CNTE les dan \$546 mil. Excelsior. Retrieved from https://www.excelsior.com.mx/nacional/2015/07/11/1034089.

Lopez-Acevedo, G. (2004). Professional Development and Incentives for Teacher Performance in Schools in Mexico. The World Bank.

Presidencia de la República. (2012). Pacto Por México. Mexico City. Retrieved from http://www.presidencia.gob.mx/wp-content/uploads/2012/12/Pacto-Por-MéxicoTODOS-los-acuerdos.pdf.

Presidencia de la República. (2013). A través de la publicación del decreto en el Diario Oficial de la Federación, se creó el 3 de octubre de 1921. [Blog] Presidencia de la República. Retrieved from https://www.gob.mx/presidencia/articulos/creacion-dela-secretaria-de-educacion-publica/.

Presidencia de la República. (2013). DECRETO por el que se expide la Ley General del Servicio Profesional Docente. Mexico City: Diario Oficial.

Roett, R. (1995). The Challenge of Institutional Reform in Mexico. London: Lynne Rienner Publishers.

Simpson, D., \& Stack, S. (2010). Teachers, Leaders, and Schools. Essays by John Dewey. Southern Illinois University Press.

Snte.org.mx. (2014). Sindicato Nacional de Trabajadores de la Educación. Retrieved from http://snte.org.mx/seccion42/secciones/20/historia-snte/.

The Glossary of Education Reform [online] Portland. Retrieved from https://www. edglossary.org/education-system/.

Vértiz Galván, M. (2017). Ensayos Históricos sobre reformas educativas en Méxic. Mexico City: la Universidad Pedagógica Nacional.

Weyl, N., \& Weyl, S. (1939). The Reconquest of Mexico: The Years of Lazaro Cardenas. New York: Oxford University Press. 